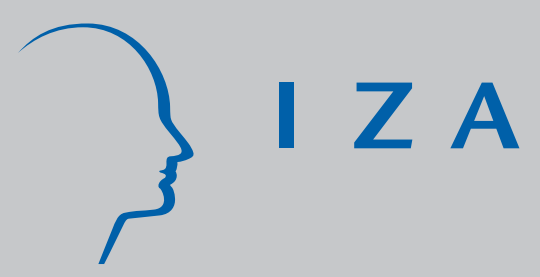

IZA DP No. 3209

Employment and Education Policy for Young People in the EU: What Can New Member States Learn from Old Member States?

Francesco Pastore

December 2007 


\title{
Employment and Education Policy for Young People in the EU: What Can New Member States Learn from Old Member States?
}

\author{
Francesco Pastore \\ Seconda Università di Napoli \\ and IZA
}

\author{
Discussion Paper No. 3209 \\ December 2007
}

\author{
IZA \\ P.O. Box 7240 \\ 53072 Bonn \\ Germany \\ Phone: +49-228-3894-0 \\ Fax: +49-228-3894-180 \\ E-mail: iza@iza.org
}

\begin{abstract}
Any opinions expressed here are those of the author(s) and not those of the institute. Research disseminated by IZA may include views on policy, but the institute itself takes no institutional policy positions.
\end{abstract}

The Institute for the Study of Labor (IZA) in Bonn is a local and virtual international research center and a place of communication between science, politics and business. IZA is an independent nonprofit company supported by Deutsche Post World Net. The center is associated with the University of Bonn and offers a stimulating research environment through its research networks, research support, and visitors and doctoral programs. IZA engages in (i) original and internationally competitive research in all fields of labor economics, (ii) development of policy concepts, and (iii) dissemination of research results and concepts to the interested public.

IZA Discussion Papers often represent preliminary work and are circulated to encourage discussion. Citation of such a paper should account for its provisional character. A revised version may be available directly from the author. 


\begin{abstract}
Employment and Education Policy for Young People in the EU: What Can New Member States Learn from Old Member States?

The EU experience with youth unemployment has changed over recent years with the launch and re-launch of the Lisbon Strategy and the Bologna process. A dramatic shift has taken place from the 1990s emphasis on labour market flexibility as a tool to abate youth long term unemployment to the more recent stress on the importance of increasing the human capital endowment via a deep reform of education and training systems. This shift is also taking place worldwide, since, as recent studies show, labour market flexibility can increase employability when the human capital level of young people is sufficiently high. To reduce the "experience gap" between young and adult people, the education systems should become of a higher quality, more inclusive to reduce the dropout rate, homogeneous to other EU countries to favour labour mobility, flexible to allow young people to better find the best match, and contemplate the duality principle, by providing training together with education, to favour smoother school-to-work transitions. Apprenticeships schemes, fiscal incentives to hire the youth unemployed as well as on-the-job training schemes should help reach objectives that cannot be guaranteed simply via an increase in labour market flexibility.
\end{abstract}

JEL Classification: $\quad$ 12, J24, J68, P3

Keywords: Lisbon strategy, employment policy, young people, economic transition

Corresponding author:

Francesco Pastore

Faculty of Law

Seconda Università di Napoli

Palazzo Melzi

Via Mazzocchi 5

Santa Maria Capua Vetere (CE)

Italy

E-mail: fpastore@unina.it

\footnotetext{
* This paper is the result of research work carried out since 2001 within a EU-TSER project on Youth Unemployment and Social Exclusion and two CERGE-EI research projects. Earlier versions of this paper have been presented at the Conference organised by PLANET GV on: "Reforming the Labour Market", Portorož, Slovenia, 29-30 November 2006; at the V International Conference in honour of Marco Biagi, University of Modena and Reggio Emilia (March 2007); and at the University of Rome "La Sapienza" (April 2007). We thank Tindara Addabbo, Roger Blanpain and Luigi Frey for useful comments. The usual disclaimer applies.
} 


\section{Introduction}

Income support and/or pro-active schemes have been at the core of the debate on economic transition from central planning to a market economy and for different reasons also at the core of the debate on the ensuing accession process to the European Union (EU). In particular, these instruments were part of the institutional and financial setting that should have helped EU accession countries define the best institutional framework during the 1990s.

In Agenda 2000 launched in 1997 under the Luxemburg Presidency, the EU Commission defined the "accession capacity" as a determinant pre-requisite, involving the adoption not only of the juridical, but also of the social, cultural, political and economic content of the so-called acquis communautaire. The ensuing pre-accession phase involved the implementation of several new policy instruments. Moreover, after entering the EU, the New Member States (NMSs) ${ }^{1}$ of Central and Eastern Europe have committed themselves also to the Lisbon and Bologna processes.

In the frames of the re-launched Lisbon Strategy underpinned by the integrated guidelines 2005-08, bringing together in a single document the Broad Economic Policy Guidelines and the Employment Guidelines, the latter adopted by the EU Council on 12 July 2005 advocate a more employment friendly stance on benefits systems focusing on promoting more Active Labour Market Policies (ALMPs) and reform tax-benefit systems, placing emphasis on shifting from passive measures of income support for the non-employed (unemployed and inactive) to pro-active policies based on training programmes, incentives for firms to hire long-term unemployed and other similar measures. The aim is to increase employability of those out of work and to help them find jobs and remain in work.

High and persistent unemployment in all OECD member states has resulted in extensive research and public debate about adequate policies to improve labour market performance. In the 1990s the OECD launched a large scale research project resulting in the publication of the OECD (1994) Jobs Study that evaluated labour market policies in the OECD member states and provided a comprehensive framework for adjusting economic policies in order to promote higher job growth and a reduction in unemployment. Among other factors, the Jobs Study proposed to increase the extent of ALMP and to investigate the interaction between tax and benefit systems and the functioning of the labour market.

The work of the OECD has also stimulated a number of empirical studies providing evidence for the effectiveness of different types of policy interventions within the OECD area. Over time a rich data base on ALMP has been developed. Evaluation of Active Labour Market Policies, which has a long tradition in the United States, has also been applied to expanded programmes of this type in many European countries. Martin (2000) and Kluve (2006), among others, give a comprehensive overview on the experiences with evaluation of the employment impact of pro-active schemes in mature market economies, including the EU-15 member states.

According to Watt (2006), it is possible to observe a shift in the OECD strategy from the 1994 Job Study until more recent years as to the role of unemployment and related benefit systems on the one hand and ALMP on the other hand. In the 1994

\footnotetext{
${ }^{1}$ The Czech Republic, Estonia, Hungary, Latvia, Lithuania, Poland, Slovenia, The Slovak Republic entered the EU in 2004. Bulgaria and Romania followed in January 2007.
} 
study, the OECD saw non-employment benefits simply as reducing the incentives to look for a job and accept offers, and also by pushing up the 'reservation wage' and thus reducing labour demand. The reassessment process has unearthed 'new evidence' that 'active labour market programmes can help offset these work disincentive effects'. The OECD has also drawn the policy lesson that if cuts in benefit levels and duration go beyond certain thresholds, this may compromise social objectives. The OECD also expresses concern about the growth of 'related' benefits, especially sickness and disability benefits. It criticises their use (as with early retirement) as a supposedly socially more acceptable 'functional equivalent' for unemployment benefit. So-called 'gate-keeping' measures are explicitly called for to address this issue. Here the shift in position is more nuanced. Generous welfare systems, especially unemployment and other benefits, are still looked upon with some suspicion, but an avenue is opened for a more 'technical' discussion about appropriate institutional measures, notably activation and ALMP policies, that counteract these negative effects. Similarly the reference to social objectives opens up a normative or political space for discussing possible efficiency/equity trade-offs.

On a critical note, according to Watt (2006), it is regrettable that the Policy Lessons did not also report the economic/efficiency arguments for decent levels of unemployment benefit that are well known in the literature; particularly that they promote efficient job match because skilled workers are not forced to take 'any job', but have a cushion that enables them to take a job more closely matching their skills (and in which they are therefore more productive).

Also the debate on young people participation on the labour market within the EU mirrors this shift from passive to pro-active schemes and again to re-evaluate the role of state support. A special focus in the EU debate, as this paper aims to show is on the reform of the educational and training systems as the core of the EU strategy to fight youth unemployment. In turn, this shift of focus on educational and training systems has its origin in the unsatisfactory impact of increasing labour market flexibility on youth unemployment in several old member states, including France, Italy and Spain.

To reduce the "experience gap” between young and adult people, country's educational systems should become of a higher quality, more inclusive to reduce the dropout rate, homogeneous to other EU countries to favour labour mobility, flexible to allow young people to better find their best match. They should also include a duality principle, and provide therefore training together with education, to favour smoother school-to-work transitions. Apprenticeships schemes, fiscal incentives to hire the youth unemployed as well as on-the-job training schemes should help reach objectives that cannot be guaranteed simply via an increase in labour market flexibility.

The outline of these notes is the following. Section one provides a historical reconstruction of the academic and policy debate on young people participation at the labour market. Section two focuses on EU countries in particular. Section three considers the new member states. Some concluding remarks follow.

\section{A historical reconstruction of the debate on young people}

Economic research on young people participation on the labour market has become central in the scientific and political debate especially in the USA already in the late 1970s and early 1980s. The main aim of early studies was to seek explanations of two key stylised facts, and namely that: a) young people have higher unemployment rate 
than their adult counterparts; b) school-to-work transitions have become increasingly longer and harder now than they used to be in the past. The answer that this research provided has become common knowledge, representing the received wisdom, which the ensuing events of the 1990s have contributed to partly overcome.

Until the late 1980s, the general feeling of economists and policy makers was based on several seminal contributions contained in an NBER book edited by Freeman and Wise (1982) on the Youth Labour Market Problem. That by Clark and Summers (1982) is a particularly interesting contribution within this book. They based their analysis on comparison of youth to adult transitions among labour market statuses (employment, unemployment and inactivity) in the USA ${ }^{2}$. This study brought to the fore a finding that was decisive in the ensuing debate on young people participation on the labour market. Young people experience much more sizeable labour market transitions compared to their adult counterparts. Especially sizeable are the transitions in and out of employment and inactivity, due to the tendency of young people to go back to education and training experiences before finding gainful employment.

The youth long-term unemployment rate is lower than that of adults simply because of the frequent unemployment spells they experience in search for the best job-worker match they can afford considering their level of education, interest and skills. When they desire a job that they cannot obtain they go back to the education and training system to attain the qualifications they need. As a consequence of their high labour turnover, however, while the youth unemployment rate is higher than average, the duration of their unemployment spells is much lower than average.

The received wisdom of the ensuing years was based on these stylised facts. They suggested a relatively optimistic view of the youth labour market problem. This, which I will call in this paper the "NBER consensus", can be summarised as follows:

a) Young people unemployment is essentially a temporary phenomenon. As such it is bound to shrink with age and, therefore, it should not worry much parents and policy makers;

b) The main reason of the difficulties that young people experience to cope with the labour market is to be found in their low level of human capital: in fact, despite their more recently achieved educational attainment, they lack the other two components of human capital, namely generic and job-specific work experience;

c) The need of young people to fill in the "youth experience gap" explains their high degree of labour turnover: young people move in and out of employment in search for the best job-worker match;

d) Often, this search requires them to go back to education and/or training schemes to obtain the knowledge, skills and qualifications necessary to change their job or their work status;

e) The fact that the adult unemployment rate is much lower than that of young people suggests that overall the market itself is able to solve the problem in the long run, at least at an individual level;

f) A sufficiently high degree of labour market flexibility, implemented, for instance, via the use of fixed-term contracts, are the best means to help young

\footnotetext{
${ }^{2}$ Clark and Summers (1982) provide also one of the first examples of analysis of the labour market dynamics based on analysis of labour market transitions.
} 
people find their best match in a shorter time, therefore reducing the gap between youth and adult unemployment rates ${ }^{3}$;

g) Fixed-term contracts provide the means for employers to pay a lower wage cost when hiring young people so to compensate them for the lower work experience and, therefore, lower productivity of young people compared to their more experienced colleagues;

h) Moreover, short-term contracts are a means for employers to "try" young people and solve the asymmetric information problem arising in the selection of personnel, while helping also young people to gain experience on-the-job rather than waiting while being unemployed;

i) In this context, any attempt to apply to young people the same compensation mechanisms as those of adult people is destined to increase the ratio of the youth to adult unemployment rate;

j) A special intervention is necessary only in few marginal cases of particularly weak young people with low levels of education attainment. Especially the dropouts from school are to be targeted by policy measures;

k) Demand side factors are important, but the way of working of the labour market is not less important: holding constant the level of aggregate demand and growth, youth unemployment dramatically differs across countries and these differences must be related to different labour market institutions, especially the degree of labour market flexibility.

In spite of the optimistic view of the NBER consensus about youth unemployment, all over the 1980s the youth unemployment rate continued to go up also as a consequence of the increasing worldwide unemployment. Moreover, due to the increasingly slow school-to-work transitions, long-term unemployment was more and more common also among young people.

This caused much concern among academicians, international organisations and policy makers, suggesting that the optimism of the NBER consensus might be ill-posed and calling for immediate intervention. If youth unemployment is not a dramatic problem and if it is going to automatically solve with time passing, why then the youth unemployment rate and also the share of youth long-term unemployment were increasing?

In fact, at the beginning of the 1990s, the aforementioned OECD Job Study (1994) re-launched the NBER consensus on youth labour market participation as a solution to reducing youth unemployment, by stressing the need for more flexible labour markets, especially in the "sclerotic" EU continent. In fact, stricter employment protection legislation was identified as the main determinant of the very high EU youth unemployment rate and high share of youth long-term unemployment. Increasing the degree of labour market flexibility and therefore the job finding rate was pointed out as the best way to reduce long-term unemployment: in fact, with a higher degree of job finding, the long-term unemployed would have had a higher chance to find a job in a given time period, reducing therefore the length of their unemployment spells.

\footnotetext{
${ }^{3}$ This view was also based on the hypothesis that long-term unemployment is generally caused by low labour turnover causing in turn state dependence. Factors from the demand (the employers' preference for supposedly more motivated short term unemployed) and from the supply side (the inevitable loss of skills due to increasingly longer unemployment spells) would cause state and duration dependence in unemployment.
} 
As a consequence, EU countries started to reduce their degree of employment protection and to ease entry into the labour market. This involved a dramatic reduction in the hiring costs for firms via the widespread use of fixed-term contracts, but only a marginal reduction in the firing costs of adult workers (see, for an analysis of the Spanish case, Bentolilla and Dolado, 1994, and the ensuing literature).

In the meantime, a different view on the causes of youth long term unemployment started to emerge in the debate. A seminal contribution by Heckman and Borjas (1980) had already shown that duration dependence in an individual's unemployment experience might be (and often is) an artefact of statistical data. In the NBER consensus, as already noted, duration dependence of unemployment is a consequence of low labour turnover: almost by chance some individuals fall into unemployment because of low job opportunities; however, once they become unemployed many individuals tend to find it difficult to obtain new employment. In fact, on the one hand, they loose their skills, while their human capital becomes obsolete; on the other hand, employers see unemployment spells as signs of scant motivation to work. Therefore, the longer people stay unemployed, the longer they remain unemployed. According to Heckman and Borjas $(1980)^{4}$, this view is not supported by empirical evidence once appropriate econometric modelling is provided. Once controlling for unobserved heterogeneity, duration dependence in unemployment disappears. More technically, the probability to find a job at a given time is not any more negatively related to the duration of the unemployment spell, but becomes flat. Therefore, long-term unemployment appears to be the consequence of the low motivation and skills of those individuals who are involved rather than of permanence in the unemployment status itself. In other words, long term unemployment does not cause itself further unemployment, but is rather a consequence of unobserved heterogeneity between employed and unemployed individuals, and among the unemployed between short and long term unemployed. The long-term unemployed experience long spells because they are less motivated to find a job and they remain unemployed because of their low job search intensity.

This innovative approach to the causes of long-term unemployment calls also for a different approach to the economic policy to fight it. If the high unemployment rate of some young people is the consequence of low motivation and skills, rather than of low job opportunities, then reducing the degree of employment protection might increase the chances only of some of the unemployed young people, not of all of them. The least motivated and skilled individuals would not benefit from greater labour turnover. They should instead be helped by employment policy in general and active labour market programmes in particular to overcome their lack of skills. Formal programmes of training might be seen in this context as a means of increasing the employability of particularly weak groups of young people.

Second, fixed-term contracts might be seen as a solution only to reduce the gap in generic, but not in job specific work experience. In fact, the short time horizon of fixedterm contracts can be seen as a strong disincentive (as already Becker, 1962, noted) for young people to invest in job specific competences for both the employer and the employee. Lower wages themselves might not be seen as a sufficient incentive to

\footnotetext{
${ }^{4}$ See also Heckman e Singer (1986); Hosmer e Lemeshow (1999); van den Berg and van Ours (1999).
} 
overcome the "youth experience gap" and therefore to provide sufficient incentives for employers to hire young people ${ }^{5}$.

According to this line of reasoning, young and adult people are hardly substitutable with each other, which suggests, in turn, that increasing labour market flexibility is not the solution to reduce the youth unemployment rate. In fact, the increasing demand for high skills caused by skill biased technical change and by sector biased international trade with less developed countries (see, for a survey, Acemoglu, 2002) is increasing the gap between a large mass of inexperienced and therefore unskilled young outsiders and the more experienced and skilled adult insiders. As noted in Bentolilla and Dolado (1994) with reference to the Spanish experience of increasing labour market flexibility, any attempt to reduce the wage for young people via an increase in fixed-term contracts, and therefore a reduction in their hiring cost for firms, will mainly increase the wage and productivity gap between insiders and outsiders, with the obvious consequence of a further increase in the youth unemployment rate.

In the more recent debate, an important role is played therefore by education and training. The impact of labour market flexibility on employment opportunities is a positive function of the educational level of the youth workforce. More educated young people might find it important to have employment experiences, even if short, because they need to and are actually more able to increase their degree of job specific work experience. Vice versa, low educated and low skilled workers might not find any benefit from short term work experience ${ }^{6}$. In other words, increasing labour market flexibility would be able to reduce the unemployment rate only if the workforce is sufficiently educated and skilled. Otherwise, it may cause only further unemployment.

This hypothesis is sometimes suggested to explain the lack of a cross-country positive relationship observed in Blanchard and Portugal (2001) between the unemployment rate and the degree of employment protection. The reason why low unemployment is achieved by both the lowly flexible Portuguese labour market and the highly flexible USA labour market might lie in the much higher educational level of the latter country. High-flexibility-high-education might be seen as a similarly good combination of complementary goods, just the same as low-flexibility-low-education. This corresponds also to the historical evolution: labour market flexibility was not a value in a traditional manufacturing based economy, say up to the 1980s, while it has become important for the efficient functioning of a modern economy based on advanced manufacturing and services, and in a world of increasingly globalised markets.

\section{The EU experience}

In OECD countries, the youth unemployment rate (15-24 years), which has slightly reduced in the last decade, still remains two times and in the EU about 1.9 times greater than that of adults. Obviously, this ratio may hide different unemployment rates across countries. It measures the specific hardship that young people experience, compared to the adults in finding a job, but is also affected by the average country's unemployment rate: it may happen, for instance, that the youth to adult unemployment ratio is

\footnotetext{
${ }^{5}$ The Nobel Prize winner, Gary Becker, had already pointed to the need to invest in job specific work experience as the reason of the worldwide diffusion of life-long jobs. Formal training is necessary in this context to raise employability more than lower wages or short term employment experiences.

${ }^{6}$ Think, for instance, of the manpower in the manufacturing sector.
} 
relatively low, although the youth unemployment rate is very high, simply because also the adult unemployment rate is high. One should therefore look also at the unemployment rate by age group to get a full picture of the youth employment problem and the hardship of school-to-work transitions. In the EU, the youth unemployment rate was $17.2 \%$ for young people and $9.2 \%$ for the adults in 2000 .

Within the EU, youth unemployment is particularly high in South Mediterranean countries. In Italy, for instance, the ratio of adult to youth unemployment was 3.8 in 2000 , with a youth unemployment rate of $32 \%$. This is the consequence of the fact that $60 \%$ of total unemployment is due to the so-called new entrants, those who enter the labour market for the first time. This is a clear indicator of the very slow school-to-work transitions experienced by young people in Italy, because of the inefficiency of the educational system and the lack of training opportunities. Consider also that, until 1997, fixed term contracts were not allowed (Caroleo and Pastore, 2000; 2005; Bottani e Tomei, 2004; Gelmini and Tiraboschi, 2006).

The EU experience with the youth employment and educational policy follows the same evolution outlined in the previous section. In the early 1990s, it seemed that labour market flexibility was the solution to the high EU youth unemployment rate. The ensuing experience of implementation of widespread labour market flexibility in Spain, France, Italy and more recently also in Germany, Denmark and the Scandinavian countries has led to a slight reduction in the unemployment rate. However, this last has remained high, much higher than in the USA. In the meantime, there is a dramatic and widespread sense of precariousness of labour market experience among young people all over the EU.

These outcomes are moving the emphasis of the debate on the issue whether the small reduction in unemployment is the consequence of insufficient labour market flexibility or rather of other factors, a number of which have been evoked in the academic and political debate (see, among others, the contributions contained in Hammer, 2003):

a) too high passive schemes, reducing the incentive for young people to search for jobs, especially in Northern EU countries;

b) in the case of Southern EU countries, strong financial support by households to the youth unemployed;

c) insufficient expenditure on pro-active schemes to ease the hiring of young people, via fiscal incentives;

d) education systems which are often unable to integrate a sufficient number of young people, especially in South European countries;

e) education systems should be more homogeneous across EU countries to ease labour mobility (Lisbon and Bologna process);

f) the quality of education is too low, programmes are sometimes obsolete and scantly linked to the labour market;

g) educational systems are in too many EU countries too much inflexible, in as much as they do not allow young people to move from one educational track to the other ${ }^{7}$. Exceptions are the UK and the Danish systems;

\footnotetext{
${ }^{7}$ An educational system can be inflexible de facto if the time necessary to obtain a degree prevents a young person from obtaining a second one in case he feels that the first degree was insufficient. This is, for instance, the case of Italy, where a student needs about 6-7 years on average to obtain a degree. Less motivated students may need often also 10 years to obtain a degree. This is a strong disincentive to obtain
} 
h) some elements of the so-called dual system, typical of Germany should be introduced also in the sequential education systems typical of other EU countries;

i) the need for more training schemes in Southern EU countries;

j) the need for a better targeting of pro-active schemes in Nordic countries.

The EU debate on the European Employment Strategy, deepened in the re-launched Lisbon agenda of the early 2000s, moves from the discontent also among neoclassical economics for the previous trust on the traditional cures for youth unemployment. First, as already discussed in the previous section, fixed-term contracts may fail to provide job-specific work experience to young people, simply because the short time horizon represents a disincentive to invest in job specific training. Temporary employment and low entry wages are insufficient to overcome this market failure. In fact, they worsen it, since employers themselves will not find it sufficient to hire young inexperienced people whose contribution to the business might be initially zero.

Another argument against labour market flexibility, already discussed in the previous section, is that numeric flexibility is unable to fight negative duration dependence of unemployment (Heckman and Borjas, 1980; Heckman and Singer, 1986; Hosmer e Lemeshow, 1999). The policy implications of both these arguments are that to fight long term unemployment labour market flexibility might not be enough. Together with increasing labour market flexibility, more active schemes, such as education, counselling and training, are necessary. Moreover, training cannot be provided only through the market, via fixed-term contracts.

The recent experience of several EU countries with increasing labour market flexibility seems to confirm this scepticism. The Spanish experience with widespread, unconstrained use of fixed term contracts suggests that this is conducive often to precarious work experiences (dead end jobs), rather than to stable employment (stepping stones).

The early Italian experience is based also on observation of some negative outcomes of the Spanish experience. In fact, Italy has introduced labour market flexibility in the form of allowing temporary employment in the 1997 Treu Law, together with several constraints to the use of short term contracts by employers, such as: a) the possibility to use temporary work only when at least part of previous workers hired with temporary contracts have been employed on a permanent basis; b) the need to hire permanently workers employed temporarily after a number of years. In 2003, a new Law, inspired by the work of Marco Biagi, takes a slightly different approach. It introduces, in fact, a number of new types of labour contracts that envisage a smaller number of limitations to the use of fixed-term contracts than the previous 1997 law $^{8}$.

A perhaps simplistic, but effective approach to the use of temporary contracts should be based on the assumption that fixed term labour contracts should be encouraged when they are established on a voluntary base. The reason for employers to hire temporary workers is to face positive demand shocks when it is not clear whether such demand shocks are temporary or permanent. Once the employers verify that such shocks are permanent, temporary contracts should become permanent. For young people,

a new degree if the students finds it difficult to find a job using the qualification obtained in her first degree.

\footnotetext{
${ }^{8}$ It is not the aim of this article to discuss the recent Italian labour law legislation. See, for an in-depth analysis, Signorelli and Tiraboschi (2004).
} 
temporary employment is voluntary when it does not last more than a given number of years, up to the time that is necessary to fill in the youth experience gap. Once young people become "adult" in terms of their employability, temporary contracts can hardly be thought as voluntary.

An important pillar of the re-launched Lisbon strategy is the educational and training system. Training should generate additional positions to those naturally yield by the market. It should be provided on a large scale, like in Germany, but also in Sweden and other Scandinavian countries. In Southern European countries, where training schemes are marginal, the educational system could be used instead as a basis for the diffusion of training schemes. In fact, the educational system is present in any part of the national territory and is often under utilised.

EU countries feature very different educational and training systems. The Scandinavian and the Central European countries have a welfare system based on a prominent role of the State and generally accompany young people with many opportunities providing them with education, training and other pro-active schemes on a large scale. England and Ireland have a market based welfare system, where the state intervenes only when the market fails. Generally speaking the education system is very efficient, while training programmes are evaluated continuously to improve it. The low share of temporary contract is explained by the fact that in this group of countries labour contracts can be interrupted in any moment with a relatively low cost. The Southern and Latin European countries, instead, have a household based welfare system. Only recently, the introduction of labour market liberalisation has provided an additional opportunity to the large number of youth unemployed. Training systems are generally underdeveloped and the government has therefore resorted to market-based training via the use of fixed-term contracts on a large scale. The lack of unemployment insurance schemes for unemployment spells intervening between two temporary employment contracts means that again it is the household that should bear the cost of unemployment.

Strong differences exist within the EU as to the type of education system. In short, two seem to be the main features of an educational system: its degree of rigidity/flexibility and the dual versus sequential principle in mixing education and training. The youth unemployment rate is generally lower in countries where the educational system is flexible and applies a duality principle.

Typically, educational systems are flexible in Anglo-Saxon countries, in Finland, Norway, Scotland and Sweden, whereas they are rigid in Central and Southern Europe. A flexible educational system makes it easy for students to move from one curriculum to another. Other aspects of a flexible educational system include: 1) the possibility to choose their educational track not too early and to have the freedom to change it later; 2) the possibility to finish educational programmes in a relatively short time. In the Anglo-Saxon countries, the Bachelor degree allows University students to obtain their degree in three years and, if they wish, to continue education at a graduate level ${ }^{9}$; 3 ) the possibility for adult people that have abandoned the educational system too early to catch up and obtain a degree with special programmes especially designed for them

\footnotetext{
${ }^{9}$ An educational system is sequential when education is followed by formal off-the-job and then informal on-the-job training; conversely a dual educational system is one where education and training coexist in several ways.
} 
(adult and life-long learning). Generally, a flexible educational system yields high education attainment rates, low dropout rates and low youth unemployment rates.

Moreover, educational systems can be sequential, like in most EU countries, or dual, like in Germany, but also in Austria, Denmark and Switzerland. The first and more common sequential system is based on the assumption that young people should enter training after they have completed formal education. The dual educational and apprenticeship system envisages that the young person goes through a period of apprenticeship or traineeship while being involved in formal education. The dual system can be school-based as well as workplace-based. A huge number of apprenticeship and vocational education schemes are combined with government-led programmes in the dual system. The apprentice is employed on a three- to four-year contract with an employer. Each year (s)he is supposed to spend a certain number of weeks in vocational school. The wage during the apprenticeship is set through collective agreements and is subsidised by the state. In this way, at the end of formal education, when seeking employment, the young person will count not only on education, but also on some work experience. In so doing, the dual system aims to prevent potential market failure in the market for firm-specific human capital. The main drawback of the dual system is that it requires a strong commitment by all parties involved. In various countries, for instance, it is difficult to create a sufficient number of apprenticeships (O’Higgins, 2001).

The sequential system is implemented with different degrees of flexibility across EU countries. Another related issue is the tendency of Southern European education systems to be centred on those students who are successful in their curricula. However, given the complexity of the system, the number of dropouts is quite high at every stage of the educational career. Until recently, no alternative in terms of training was offered to these young people. In fact, ALMP expenditure is traditionally very low. Marketbased systems of training, such as temporary contracts, have been introduced only recently on a large scale in Spain and moderately in Italy. As a consequence, especially in high unemployment areas, school dropouts foster a stagnant unemployment pool.

Northern European countries have a more flexible sequential education system and, hence, more efficient school-to-work transitions. The Northern education system is commonly characterised by a three-track system: a general education track that leads to work through higher education; a vocational track, and a work-training and/or apprentice track. Young people do have to make choices early in their lives concerning which 'pathway' they want to pursue, but they have the opportunity to move from the vocational to the academic pathway and vice versa. The Nordic system is characterised by a low dropout rate and by higher expenditure in training for school dropouts. As noted in Calmfors et al. (2002), over the 1990s, a period of emerging unemployment, ALMP was given the role of closing the circle of sequential education systems in Sweden, providing the last resort of human capital formation on a large scale.

The Northern European system also has drawbacks. The main problem is the cost and the unavailability of young people and/or firms to attend or organise the pathways foreseen by policy makers. Moreover, the 'stigma' surrounding some training schemes in northern countries has encouraged young people to feel very reluctant to participate (for England, see O’Higgins, 2001, p. 119).

There are differences in the effectiveness of the two systems. A beneficial consequence of the dual system in Germany is the low youth unemployment rate, which was 9\% for young adults (18-24 years) against a EU average of 19.1\% in the second half of the 1990s. The gap with the prime-age (25-54 years) unemployment rate has 
been almost closed. Nonetheless, young adults (20-24 years) tend to have slightly higher unemployment rates than the teenagers (15-19), which is a peculiarity of Germany (O’Higgins, 2001, Figure 2.1). This could be due to the fact that some teenagers easily find a job during their apprenticeship, only to lose it later. Therefore, in some cases, the German system tends simply to postpone, rather than eliminate the risk of unemployment. The unified Germany has represented an important testing ground for the dual system. The increasing unemployment rate of the 1990s suggests that the dual system works well when the average unemployment rate is low.

Although higher than in countries adopting a dual system, the unemployment rate of young people in northern European countries is traditionally lower than in Southern European countries: for those aged 18-24, in 1997, it was 17.8\% in Sweden and 34.2\% in Spain. The rigid sequential system is often associated with high and persistent youth unemployment.

Confirming a finding of the literature relative to the previous decades, the youth unemployment rate also noticeably decreased in the second half of the 1990s, together with the average unemployment rate.

Another important factor of youth unemployment is the household. It is well-known that those young people who experience long unemployment spells and, therefore, marginalisation when not social exclusion have inherited a poor economic and educational background from their families. This is one way through which household remain in a poverty trap from one generation to the next. Specific interventions are envisaged to avoid young people with a poor family background to dropout from education and to have training opportunities when out of the educational system.

Reducing youth unemployment, especially long-term unemployment, is one of the main objectives of the EU employment policy. According to the European Employment Strategy defined already in the late 1990s, every member state should provide an employment or training opportunity to young people within six months of their unemployment spell.

All over Europe, various proactive schemes have been implemented in the past two decades as a consequence of the implementation of the Lisbon strategy. According to international conventions, they include: (i) job-broking activities with the aim of improving matching between vacancies and unemployed; (ii) labour market training; and (iii) job creation (subsided employment). Training schemes, such as work and training contracts, apprenticeships and scholarships, are considered the most suitable measures for young people, as they activate the accumulation of human capital necessary to find gainful employment.

\section{The case of Transition countries}

The labour market position of young people in the new member states is on average worse than the EU average and close to that in Southern European countries (O'Higgins, 2005). The ratio of the adult to youth unemployment rate fluctuates between 2 and 3 from one country to the other. Beleva et. al. (2001) find a ration of 2.1 for Bulgaria, whereas Pastore (2005) and Domadenik and Pastore (2006) find a ratio of 2.8 for Slovenia and 3 for Poland.

To fully understand the recent debate and policy orientation towards contrasting passive income support versus pro-active schemes in the case of new member states one should consider first the debate relative to the late pre-transition and to the early 
transition period. Previous opinions regarding benefit schemes and their use by the pervasive welfare system existing during the Socialist period and by the politically weak and inexperienced post-transition governments for the alleviation of the unemployment generated during transition will surely affect the current and future debate on passive and active labour market policy for the unemployed and inactive people.

During the socialist system, in Central and Eastern European Countries (CEECs), workers were used to a pervasive welfare state. Unemployment was virtually nonexistent due to the commitment of socialist regimes to full employment as a way to exploit all the labour surplus available (Kornai, 1992), but this implied also the commitment of state firms to provide jobs for all, though at very low wages. Moreover, the state used to provide also several other benefits to the most in need as well as free social services for all, including childcare facilities, health care, hospices and other services for the elderly. This was possible thanks to very soft budget constraints for state firms, the hidden state budget deficit and strong unions.

When transition began unemployment started to emerge as a new reality and with it a debate started on the need to introduce some kind of employment protection legislation, state subsidies to the unemployed, early retirement schemes and support to inactive people. This type of new welfare started under the auspices of the early Optimal Speed of Transition models (Aghion and Blanchard, 1994), which suggested that passive income support schemes might be useful to buy out workers from state owned enterprises and win their resistance to the reform process. At that time, the emphasis on rapid restructuring versus gradualism was dramatically affected by the fear of a return to the past and the need to make the transition process irreversible. This way of thinking found an encouraging consensus in the population as well as in all political parties worried to make the increasing unemployment, inequality and poverty socially acceptable. Also a widespread feeling was that the state, not the households should bear the social cost of reforms. The almost immediate consequence was the explosion of the social public expenditure, the pressure on the pension system, the dramatic increase of the dependency ratio, all factors that led the CEECs state budget to the edge of a dramatic collapse.

Only in the late 1990s, when transition seemed to have become irreversible and state budget were suffering dramatic imbalances, the debate has shifted from the gradualism/shock therapy debate to a debate on the optimal design of labour market institutions. Two streams of literature have emerged. Some scholars (Boeri, 2000) started to point to passive schemes as the origin not only of threat for the financial and monetary stability, but also as a source of social distress for the actual way of working of the labour market and, consequently, for the speeding up of a transition process which seemed to experience a dramatic slow down. Boeri (2000) claimed that the right sequence for the implementation of non-employment benefits would be the opposite of that actually followed: the governments should have started from low passive income support schemes to facilitate the flow from the state sector to non-employment and back to employment in the private sector. Only at a later stage, when unemployment was really involuntary, the governments should have started to provide income support to the losers of transition, namely those who were actually not employable in the private sector. Other scholars (Micklewright and Nagy, 1999; 2002) advocated that the sequence of reforms was the right one and that income support schemes in the early stages of transition were indeed necessary to help people bear the dramatic early stages 
of the transformation. Moreover, in the early stages of transition, unemployment was essentially probably involuntary, whereas later when long-term unemployment started to emerge, unemployment benefits should have been reduced to increase incentives to work for unemployed people. Finally, unemployment benefits have been very low in CEECs also compared to the low average wages.

Also in new member states, youth unemployment is worrisome, among other reasons, because it contributes to make harder a dilemma that the Lisbon strategy defined by the Special EU Council of March 2000 aims to fight, by suggesting the importance for young people of investing in human capital accumulation for the future of Europe as "the most competitive and dynamic knowledge-based economy in the world capable of sustainable economic growth with more and better jobs and greater social cohesion". Young people in CEE have to face a trade-off between continuing to invest in their own education, therefore reducing the household's budget, on the one hand; and accessing immediately the labour market, therefore contributing to the household income, but reducing their own chance to find gainful employment in the future, on the other hand.

As noted in Pastore (2005), the case of Poland is typical of the changes new member states are currently facing. Poland is the transition economy experiencing the highest degree of structural change and the highest unemployment rate in the area. It adopted a Big Bang approach to the reform process, by introducing simultaneously price and trade liberalisation, together with privatisation and macroeconomic stabilisation already in the early 1990s. A massive flow of foreign direct investment has triggered the process of technological change, on the one hand, and generated the need for skill upgrading of the workforce, especially of the youngest segments, on the other hand.

Over the years, similar to other transition countries, the share of individuals with high education attainment has dramatically increased in Poland, together with the progressive abatement of the share of people with vocational secondary degrees (Boeri, 2000). Domadenik and Pastore (2006, Tab. 5 and A5) find that from 1997 to 2002 the percentage of young teenagers (15-19) in education increased from about 84 to 88, while that of young adults (20-24) increased from 20 to 31. The corresponding figures for the early 1990s were 45 and 13 percent respectively. In both cases, Poland seems to be close to the educational targets fixed within the Lisbon strategy for the year 2010 .

However, these figures raise an important issue, namely what is the reason of the striking contrast between the excellent (at least quantitative) achievement in educational attainment and the delay in increasing employment and unemployment rates, which remain well below the Lisbon objectives.

\section{Concluding remarks}

The EU experience with young people unemployment has changed over recent years with the launch and re-launch of the Lisbon Strategy and the Bologna process. A dramatic shift has taken place from the 1990s emphasis on labour market flexibility as a tool to abate youth long term unemployment to the more recent stress on the importance of increasing the human capital endowment via a deep reform of education and training systems. This shift is also taking place worldwide, since, as recent studies show, labour market flexibility can increase employability when the human capital level of young people is sufficiently high. To reduce the "experience gap" between young and adult people, the education systems should become of a higher quality, more inclusive to 
reduce the dropout rate, homogeneous to other EU countries to favour labour mobility, flexible to allow young people to better find the best match and contemplate the duality principle, by providing training together with education, to favour smoother school-towork transitions. Apprenticeships schemes, fiscal incentives to hire the youth unemployed as well as on-the-job training schemes cannot guarantee the same objectives as an increase in labour market flexibility. 


\section{References}

Acemoglu, D. (1992), “Technical Change, Inequality, and the Labour Market”, Journal of Economic Literature, 40(1): 7-72.

Aghion, P. and O. Blanchard (1994), "On the Speed of Transition in Central Europe”, NBER Macroeconomics Annual, 283-320.

Becker, G. (1962), “Investment in Human Capital. A Theoretical Analysis”, Journal of Political Economy, 70(5): 9-49.

Beleva, I., A. Ivanov, N. O’Higgins e F. Pastore (2001) “Targeting Youth Employment Policy in Bulgaria”, Economic and Business Review, vol. 3, n. 2, pp. 113-135.

Bentolila, S., e Dolado, J.J. (1994), "Labour Flexibility and Wages: Lessons from Spain”, Economic Policy, 18: 54-99.

Blanchard, O. e Portugal P. (2001), "What hides behind an unemployment rate: Comparing Portuguese and U.S. unemployment”, American Economic Review, 91(1): 187-207.

Boeri, T. (2000), Structural Change, Welfare Systems, and Labour Reallocation. Lessons from the Transition of Formerly Planned Economies, Oxford University Press, Oxford.

Bottani, N., Tomei, A. (2004), "La difficile transizione dalla scuola al lavoro", www.lavoce.info, 9 Settembre.

Calmfors, L., Forslung, A. and Hemström, M. (2002), "Does active labour market policy work? Lessons from the Swedish experiences”, IFAU- Institute for Labour Market Policy Evaluation, Working paper, no 4.

Caroleo F.E. e F. Pastore (2000) “Le politiche del lavoro in Italia alle soglie del 2000”, Osservatorio ISFOL, n. 6, pp. 75-121.

Caroleo F.E. and F. Pastore (2001) "How Fine Targeted is Active Labour Market Policy to the Youth Long Term Unemployed in Italy?”, CELPE Discussion Paper, Università di Salerno, n. 62, Settembre.

Caroleo F.E. and F. Pastore (2003) "Youth Participation in the Labour Market in Germany, Spain and Sweden”, in T. Hammer (op. cit.).

Caroleo F.E. and F. Pastore (2005) "La disoccupazione giovanile in Italia. La riforma della formazione come alternativa alla flessibilità”, Economia e Lavoro, 39(2): 49-66 (also available in P.R. Gelmini and M. Tiraboschi, (2006), op. cit., Chap. 2; and as CELPE Discussion Paper, n. 83, October).

Clark, K. B. and L. H. Summers (1982), “The Dynamics of Youth Unemployment”, in Freeman, and Wise (eds.), The Youth Labour Market Problem: Its Nature, Causes 
and Consequences, University of Chicago Press/NBER, Chicago (also available in Summers, L. H. (1990), Understanding Unemployment, MIT Press).

Domadenik, P. e F. Pastore, F. (2006) "Influence of Education and Training Systems on Participation of Young People in Labour Market of CEE Economies. A Comparison of Poland and Slovenia”, International Review of Entrepreneurship \& Small Business, 3(1): 640-666.

EU (1997), Agenda 2000, EU Commission, Luxembourg.

Freeman, R. B. and D. A. Wise (eds) (1982). The Youth Labour Market Problem: its Nature, Causes and Consequences. Chicago: U. of Chicago/NBER.

Gelmini, P.R. and M. Tiraboschi (2006, eds.), Scuola, Università e mercato del lavoro dopo la Riforma Biagi, Giuffrè, Milano (collana Adapt - Marco Biagi Foundation).

Hammer, T. (2003), Youth Unemployment and social Exclusion in Europe, Policy Press, UK: Bristol.

Heckman, James J. and George J. Borjas. 1980. "Does Unemployment Cause Future Unemployment? Definitions, Questions and Answers from a Continuous Time Model of Heterogeneity and State Dependence” Economica, 47(187): 247-83.

Heckman J. J. and B. Singer (1986), "Econometric Analysis of Longitudinal Data”, in Z. Griliches e M. D. Intriligator (1986), Handbook of Econometrics, Elsevier.

Hosmer, D.W. and S. Lemeshow (1999), Applied Survival Analysis, Wiley \& sons, New York.

Kluve, J. (2006), “The Effectiveness of European Active Labour Market Policy”, IZA Bonn, discussion paper n. 2018.

Kornai, J. (1992), The Socialist System. The Political Economy of Communism. Oxford, Oxford University Press.

Martin, J.P., (2000), "What works among active labour market policies: Evidence from OECD countries’ experiences, OECD Economic Studies 30, 79-113.

Micklewright, J. and G. Nagy (1999), "Living Standards and Incentives in Transition: The Implications of Exhausting UI Entitlement in Hungary”, Journal of Public Economics, 73(3): 297-319.

Micklewright, J. and G. Nagy (2002), “The Informational Value of Job Search Data and the Dynamics of Job Search: Evidence from Hungary”, Acta Oeconomica, 52(4): 3999-419.

OECD (1994). “The OECD Jobs Study”, OECD Publications, Paris.

O’Higgins, N. (2001), Youth Unemployment and Employment Policy: A Global Perspective, ILO, Ginevra.

O'Higgins, N. (2005) "Trends in the Youth Labour Market in Developing and Transition Countries," Labor and Demography 0507002, EconWPA.

Pastore F. (2005) "To Study or to Work? Education and Labour Market Participation of

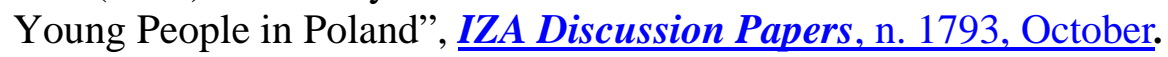


Ryan, P. (2001), “The School-to-Work Transitions: A Cross-National Perspective”, Journal of Economic Literature, 39(1): 34-92.

Signorelli, M. and M. Tiraboschi (2004), Mercato del lavoro, norme e contrattazione. Scritti in memoria di Marco Biagi, Edizioni Scientifiche Italiane, Napoli.

Van den Berg G.J. and J.C. van Ours (1999), "Duration Dependence and Heterogeneity in French Youth Unemployment Durations”, Journal of Population Economics, 12(2): 273-285.

Watt A. (2006), "Assessing the reassessment of the OECD Jobs Strategy: eppur si muove?" European Economic and Employment Policy Brief - ETUI-REHS, No. 2. 